\title{
Is there One Pattern of Earnings Management Motivations Fit all Contexts? An Empirical Study
}

Nargis Kaisar Boloes Makhaiel

Lecuter at Accounting Departement-

Faculty of Commerce, Tanta University 


\title{
Is There One Pattern of Earnings Management Motivations Fit All Contexts? An Empirical Study
}

\author{
Dr. Nargis Kaisar Boloes Makhaiel \\ Lecuter at Accounting Departement- \\ Faculty of Commerce, \\ Tanta University
}

\begin{abstract}
This paper aims at exploring the effect of the Egyptian context on shaping executives' motives to manage earnings; and identifying the most influential managerial motives: managerial self-interests and external environmental factors. The research adopts an interpretative methodology and interview methods. Interviewees were conducted with twenty managers representing five different companies within industrial and service sectors of the Egyptian economy. The findings of this research suggest that a firm's context has an influence on shaping managers' self-interests and that in Egypt the job market is a powerful motive for managing the financial reports, followed by cash bonuses; however, stockbased compensation lacks the power to motivate managers into making such financial improvements. In addition, this paper concludes that environmental motives are more important than motives related to managers' self-interests, because managers cannot achieve their own interests without complying with the external pressures or motives to manage the financial reports. The principal contribution of this paper is to build on the previous earnings management literature to consider the firms' context while studying managers' motives. It pairs the economic factors with institutional factors to form the main reasons behind: 1) managers' engagement in earnings management; and 2) the superiority of environmental factors over the managerial selfinterests motives. It also sheds light on, there is no one pattern of earning management motivations fit all contexts. This paper also contributes to the new institutional sociology literature by bringing managers' interests and power into the centre of the conceptual framework.
\end{abstract}

Keywords: Earnings Management Motives, New Institutional Sociology, Managers' self-interests, External Motives, Managers Power, Egypt. 


\section{Introduction:}

As Degeorge et al. (1999) argue, earnings recorded on executives' "watch" explicitly and implicitly determine their rewards e.g. employment decisions and compensation contracts. Noting that makes managers' own self-interests exert pressure on them to alter the reported earnings figures for the sake of serving such interests. Consequently, executives can be motivated to distort reported earnings in a self-serving manner (ibid.).

It has been argued that attempts by managers to adjust reported income for the sake of painting a favourable financial image of the firm derive not only from executives' self interests but also from company's interest and reputation with outsiders. These incentives include: 1) Equity-based executives' compensation (Bange \& De Bondt, 1998; Bushee, 1998); 2) Maximizing managers' bonus contracts (Bange \& De Bondt, 1998; Burgstahler \& Eames, 2003; Watts \& Zimmerman, 1990); 3) Securing executives' jobs and enhancing their career image and professional reputation (Bange \& De Bondt, 1998; Graham, et al., 2005; Matsunaga \& Park, 2001); 4) Addressing the need to attract new funds (Bushee, 1998); and 5) Relaxing the debt contracts (Burgstahler \& Eames, 2003; Watts \& Zimmerman, 1990); 6) Attracting skilled Employees; Meeting Stock Exchange Market's (EGX) rules; Beating earnings targets; and Economic privatization programme (Makhaiel and Sherer, 2017). These earnings management (EM) motives, in turn, can be classified into two sorts of motivations. The first is external motivations, aiming at enhancing the firm's reputation with outsiders e.g. stakeholders, creditors, employees, and Stock Exchange; the second is managerial motivations related to achieve managers' own self-interests e.g. increasing executives' compensation packages, securing their employment, and enhancing their professional reputation.

Although prior studies have individually documented that executives are able to game the perceptions of outside parties; the committees of directors who determine their compensation plans i.e. the value; and the nature of compensation; or job market; they nonetheless contain gaps which need to be addressed. Those gaps are generated by many factors including: studying managers' self-interested motives in isolation of their context by emphasizing the cause/effect approach; ignoring the use of 
appropriate theory for giving clear insight into those motives; the lack of research concerning the EM phenomenon in Arabic countries including Egypt, and a lack of attention given to either the job market's influence on managers' propensity to improve the financial reporting (FRs) or to managerial intentions to manage profits so as to serve their own interests through achieving their firm's interests.

In order to address those gaps, this paper aims at exploring the effect of the Egyptian context on shaping executives' self interests that encourage them to manage FRs by using new institutional sociology (NIS) theory in order to derive a deeper explanation for such phenomena in Egypt. Analysis of executives' views and attitudes, collected from eleven semi-structured interviews, has produced empirical evidence which is consistent with the theory's suggestions. The results suggest that, in the Egyptian context, increasing cash bonuses, protecting managerial jobs, and enhancing their professional career and reputation are influential motives for corporate executives to improve the FRs; in contrast to findings of research conducted in other contexts e.g. US, stockbased compensation has no effect on motivating them to make such financial improvements.

The second purpose of this paper is to explore the relationship between two types of managerial motivations: external contextual motives; and managers' self-interests and to identify the most influential and important motives among managerial self-interests for improving FRs. Accordingly, this paper addresses another omission in the previous literature, which is its neglect of the relationship between different kinds of managerial motives to identify the most influential factors. It has been found that corporate executives are concerned with meeting external parties' predictions in order to enhance the firm's relation with such parties as a basic step towards achieving their own interests; executives could not achieve their own self-interests without complying with these external motives. It has also been evidenced that job market motives i.e. job security and professional reputation and career, are considered as more important incentives for improving the FRs than cash bonuses, because it is deduced that achieving job market motives is the cornerstone and basic step to achieve executives' monetary compensation i.e. cash bonuses not the opposite. 
This paper also provides evidence that there is no single managerial motive for improving the financial image of the firm; there is a package of different interests, including external pressures and the self-interested motives that corporate executives seek to achieve. This is consistent with Rezaee's (2005) argument that economic motives are paired with other motives such as egocentric and ideological motives to form the main reasons behind managers' engagement in EM. This paper also contributes to the NIS literature by bringing managers' interests and power into the centre of the conceptual framework; it is theoretically argued that executives' interests and power are used as dynamics for reacting to the external environmental pressures to improve the FRs.

The remainder of the paper has five sections. The first section reviews the previous literature pertaining to managerial selfinterested motivations; the second section considers the conceptual framework; the third section describes the methodology and data collection technique; the fourth section contains the empirical findings and results; while a discussion and conclusions are the focus of the final section.

\section{Literature on Motives Pertinent to Managers' Self- interests:}

In light of reviewing the prior literature, executives' self-interests as EM motives can be divided into different groups: (1) compensation packages including (a) bonus incentives, (b) stock compensation incentives; and (2) job market incentives involving (a) securing current job, (b) enhancing professional career.

\section{Managerial Compensation Package Motives:}

Dechow and Sloan (1991) and Crocker and Slemrod (2007) argue that the association between the reported earnings and the executive compensation package has led to some corporate financial scandals of the early twenty-first century and has revealed the "darker side" of executives' performance-based compensation packages. It is argued that when a firm provides its executives with a performance-based incentive package, either a bonus or stock-based compensation plan. It actually provides its managers with motives for choosing increase-earnings accounting methods and misreporting the true information about the firm's underlying transactions in order to propel the earnings number 
upward and hence also to boost its compensation package. Therefore, "some degree of earnings management must be tolerated as a necessary part of an efficient agreement" (Crocker \& Slemrod, 2007: 698; Dechow \& Sloan, 1991; Hagerman \& Zmijewski, 1979; Healy, 1985; Rezaee, 2005; Watts \& Zimmerman, 1978).

The literature often breaks the executive's compensation package into two components: cash bonus schemes; and stock-based compensation contracts, as explained below.

\section{Bonus Scheme Motives}

Previous research hypothesizes that the positive association between the reported accounting earnings and the executive's annual bonus plans creates managerial impetus to opportunistically choose income-boosting accounting methods for the sake of increasing the firm's reported income, which in turn leads to a rise in managers' awards and bonuses

(Balsam, 1998; Bange \& De Bondt, 1998; Bowen, et al., 1995; Dechow \& Sloan, 1991; Pergola, 2005; Subramaniam, 2006; Watts \& Zimmerman, 1978, 1990). Moreover, Smith and Watts (1982) assert that making decisions related to the firm's real activities e.g. investment and finance decisions, can also be influenced by executives' annual bonus plans. To date, there has been a vast volume of existing research which empirically supports the previous hypothesis about the role of the bonus scheme as an economic motive for managing earnings (Abdel-Khalik, 1985; Balsam, 1998; Hagerman \& Zmijewski, 1979; Healy, 1985; Healy, et al., 1987; Matsunaga \& Park, 2001; Moses, 1987). In contrast, Graham et al.'s (2005) survey and interview of managers do not support the executives' bonus motivation, since managers claimed that their bonuses are related to internal earnings targets, and not to external earnings. This is consistent with Healy's (1985) suggestion that conflicting results from the research concerning the motivational role of the bonus scheme are derived from different definitions of earnings figures, which are included in each scheme that the executives are awarded.

\section{Stock-based Compensation Motives}

Over the last two decades the structure of executive compensation plans has changed (Bartov \& Mohanram, 2004); in particular, stock-based compensation schemes have been enormously 
increased (Bergstresser \& Philippon, 2006). Such compensation plans generate a sensitive relationship between the firm's executives' wealth and the firm's stock price (Cheng \& Warfield, 2005; Dechow \& Sloan, 1991). Therefore, its role in rewarding the corporate executives has recently come under scrutiny (Burns \& Kedia, 2006). Both regulators and investors have directed significant attention towards stock-based executive compensation plans as a managerial incentive for manipulating earnings (Cheng \& Warfield, 2005). Prior research has supported the negative side of stock-based compensation plans by providing evidence about the strong positive association between overstating or making up a substantial part of a firm's reported earnings within the period, which has seen abnormally large amounts of stock options being exercised and abnormal sales figures for the firm's stocks (Bartov \& Mohanram, 2004; Beneish, 1999 a; Beneish, et al., 2001; Beneish \& Vargus, 2002; Bergstresser \& Philippon, 2006; Cheng \& Warfield, 2005; Cheng, 2004).

\section{Labour Market Motives}

Graham et al. (2005) and Bange and De Bondt (1998) report evidence that job security (or turnover) and career image and professional reputation play an important role in adjusting the firm's financial report. Most of the current literature suggests dividing job market incentives into two main groups: maintaining the current managerial employment, and enhancing managers' professional reputation and career.

\section{Job Security Motives}

It is acknowledged that securing employment is tied up with reported earnings, stock price performance or both, and hence it is considered as a motive for managing earnings (DeAngelo, et al., 1994; Degeorge, et al., 1999; Pourciau, 1993). Academics have provided empirical evidence about the strong association between poor financial performance and the threat of job losses (Gilson, 1989; Gilson \& Vetsuypens, 1993; Weisbach, 1988). Graham et al. (2005) also find that the CFOs whom they interviewed were willing to refuse positive NPV project in order to beat the analysts' forecasts for the sake of securing their employment. Similarly, DeFond and Park's (1997) findings support the theory claiming that managers deliberately smooth earnings figures for the sake of job security. Furthermore, other empirical findings demonstrate the job market penalties for managers who violate 
GAAPs, in terms of the high level of turnover of culpable managers after the announcement of financial restatements (Arthaud-Day, et al., 2006; Desai, et al., 2006; Feroz, et al., 1991; Karpoff, et al., 2008 b). However, both Agrawal et al. (1999) and Beneish (1999 a) refute both the job market penalties and the SEC's monetary sanctions for managers caught engaging in fraud.

\section{Professional Reputation Motive}

Fama and Jensen (1983) hypothesize that there are incentives for managers to enhance their professional reputation and their value as human capital within the job market, as a good reputation enhances the possibility of getting better employment in the future (Subramaniam, 2006). Researchers have found that managers of high repute manipulate reported earnings to beat earnings targets for the sake of maintaining their professional reputation and signalling their competence in the long term, because a repeated failure to meet such targets negatively affects managerial reputations (Bartov, et al., 2002; Francis, et al., 2008; Gunny, 2010). Another stream of literature has provided evidence about the job market penalties in terms of reduced opportunities for sacked managers who lose their professional reputation due to engaging in fraudulent financial disclosure or violating GAAPs. These penalties manifest either as difficulties in being rehired or getting a better job, or at least a job equal to the previous one. In addition to these job market impediments, the SEC creates obstacles that make it difficult for sacked managers to be engaged as officers and directors of public companies (Desai, et al., 2006; Karpoff, et al., 2008 b; Kedia \& Philippon, 2009).

\section{Gaps in Existing Literature}

A review of the previous literature has highlighted four gaps, and addressing these gaps provides the motivations for this paper. The first is the environmental gap, which has emerged due to neglect of the influence of the firms' context on identifying executives' compensation schemes and on managers' propensity to manage earnings to serve their own interests. That is, the existing literature has made an environmentally-free assumption, focusing on investigating managerial motives in isolation of their context. However, Doupnik and Richter (2003) and Perera (1989 a) point out that national culture is shaped by various ecological factors such as history, geography, climate, language, economy, 
demography, technology and religion. Perera (1989 a) takes the view that those cultural factors affect the legal system, capital market and corporate ownership within a nation. The same argument can be applied for the effect of cultural factors on a firm's culture and on defining the firm's regulatory rules and company laws, which include identifying the managers' compensation plans. In addition, Gray (1988) suggests that it is expected that accountants' and managers' attitudes and behaviour will be guided by these cultural values. This indicates that the culture of a nation affects not only its socioeconomic structure, e.g. legal system and company laws, but also societal attitudes, motives and self-interests.

The second gap is due to the lack of consideration given to the job market's influence on motivating managers, although some research has attempted to address such motives. In addition, there is a lack of research investigating managerial intentions to make real financial improvements in order to serve their own interests as well as those of the firm; previous research has tended to focus on either violations of accounting standards or abuse of real business activities.

The relationship between different types of motives constitutes the third gap: although accounting literature on EM motivations sheds light on different categories of managerial motives, there is no research that has given due consideration to exploring the relationship between them or establishing which motives are most powerful and thus act as drivers for others. Therefore, this creates a need to explore the relationship between different categories of motivations.

The fourth gap concerns the almost universal adoption of a positivist methodology which fails to capture the effect of the role of contextual elements of reality in shaping managers' selfmotives. Instead, an interpretive approach provides an alternative perspective and a methodological approach that enhances our understanding of managerial self-interested motivations in their wider economic and social context. 


\section{The Extension of the New Institutional Sociology Theory (NIS): Managerial Self-interests Dynamic for Improving Financial Reports}

The application of NIS theory suggests that several factors in the Egyptian context encourage firms' managers to improving the FRs. Those environmental factors include: financial suppliers i.e. investors and creditors; other stakeholders i.e. employees; Egyptian Stock Exchange (EGX) rules; beating an earnings target; executives' personal characteristics and beliefs; and economic factors i.e. the adoption of the privatization programme, all of which pressures act as motives for improving FRs. However, NIS is still unable to explain how managers react to such motives or pressures in order to benefit themselves. This led Moll et al. (2006: 188, emphasis added) to state that: "This typically 'macro' focus, which has dominated the new institutional approach has recently been subject to much criticism".

\section{Shortcomings of NIS}

DiMaggio (1988: 8) argues that the NIS model is incapable of demonstrating why some organizational changes receive support from organizational actors while others do not. This criticism is due to a twofold assumption of the NIS model: 1) the constrained organizational environment; 2) the silent position of organizational actors in responding to environmental pressures.

Influence of Constrained Organizational Context

NIS pays relatively 'one-sided attention' to institutionalization at the macro level i.e. environmental and institutional level, assuming a "supraorganizational" or constrained field (DiMaggio1988; Modell, 2002; Powell,1991). Thus, organizational practices and behaviours inevitably result from the accommodation or application of institutions (i.e. practices, ideas and beliefs) generated in the organization's institutional environment (DiMaggio \& Powell, 1991; Greenwood \& Hinings, 1996; Scott, 1987), as legitimate and unquestioned ways of doing things (Carpenter \& Feroz, 2001; Meyer \& Rowan, 1977; Oliver, 1992; Zucker, 1987). That is, the organizational environment provides "templates for organizing" or "archetypes" to be adopted by firms (DiMaggio \& Powell, 1991: 27; Greenwood \& Hinings, 1996); such implementation is behind the control, agreement or interests of the firm's members (Carpenter \& 
Dirsmith, 1993; Carpenter \& Feroz, 2001; Meyer \& Rowan, 1977; Shapin, 1982).

\section{The Silent Position of Organizational Actors}

The imagery of the institutional perspective depicting the organizational environment as overly constrained leads us to consider the orgainzations and their actors as severely constrained, powerless, lacking pro-active agency ${ }^{1}$, and passive in responding to environmental pressures (Brint \& Karabel, 1991; DiMaggio, 1988; Greenwood \& Hinings, 1996; Modell, 2002; Powell, 1991; Zucker, 1987). Perrow (1985: 154- emphasis added) makes this point clear by highlighting that:

"The neglect of power and group interest issues leads to some distressing examples of...cynicism about the motives of reformers, reformers are scorned. They are labeled disorder-discovering interest groups"

DiMaggio (1988) argues that the interest/power-free model of institutional theory is based on two assumptions. First, there are factors which make it difficult for organizational agents to either realize or act on their own interests; second, in spite of these factors, those agents are able to realize and act in their interests, but circumstances prevent them from doing so effectively. Thus, they unwittingly accede to the contextual prevailing templates as an unchallenged and a proper way of doing things (Greenwood \& Hinings, 1996).

Viewed in this light, it is clear that NIS has neglected the role of actors' interests and agency in formulating their decisions or actions (Carpenter \& Dirsmith, 1993; Carruthers, 1995; Covaleski \& Dirsmith, 1988; DiMaggio, 1988; DiMaggio \& Powell, 1991; Oliver, 1992; Perrow, 1985; Powell, 1985).

DiMaggio (1988: 3) asserts that "yet the role of interest and agency in institutional theory remains somewhat obscure", as there is 'no explicit or formal theory' for the role of group interests in the institutionalization process. This fault highlights why DiMaggio's initial analytical strategy does not succeed in adequately explaining the reasons behind institutionalization

${ }^{1}$ Take, for instance, DiMaggio's and Powell (1983) work which expresses the organizational silence by using the concept of the 'iron cage', which portrays human actors as powerless and "inter in the face of inexorable social process" (DiMaggio, 1988: 10). 
(acceptance) or deinstitutionalization (rejection) of certain practices to be applied within the firm (Friedland \& Alford, 1991). Nor does it provide a satisfactory answer for DiMaggio's and Powell's ( 1991: 29) question that, "if institutions exert such a powerful influence over the ways in which people can formulate their desires and work to attain them, then how does institutional change occur?".

NIS theory needs to be more considerate of, and open to, the interaction between the firm and its institutional environment and to bring actors' interests and power more centrally onto the institutional stage (Brint \& Karabel, 1991; Collier, 2001; DiMaggio, 1988; Tsamenyi, et al., 2006). As a result, Moll et al. (2006), Collier (2001) and DiMaggio (1988) call for the political model to be more closely integrated with the institutional model, arguing that:

"The theory requires greater integration with micro explanations and ... incorporating the intra-organizational processes and the interests and generative capacity of actors into perspective ... [there is a need] for a more complete account for understanding the emergence, persistence and abandonment of institutions ${ }^{2}$ [accounting practice]". (Moll et al, 2006, p.188 emphasis added)

\section{Extending NIS to Overcome the Critcisms}

Overcoming this shortcoming involves the necessity for NIS to be expanded to include organizational actors' power and interests, especially in relation to the important role of such power, interests and actions in determining whether the adoption of certain accounting practices have been applied or rejected (DiMaggio, 1988; Granovetter, 1985) and empirically evidenced by the vast volume of accounting research, which includes: (Barley \& Tolbert, 1997; Burns, 2000; Burns \& Scapens, 2000; Carpenter \& Dirsmith, 1993; Collier, 2001; DiMaggio, 1988; Greenwood \& Hinings, 1996; Hopwood, 1987; Kholeif, et al., 2007; Modell, 2002; Moll, et al., 2006; Oliver, 1992; Powell, 1991; Scapens \& Roberts, 1993; Tsamenyi, et al., 2006).

Expanding NIS leads organizational actors to be viewed as "more plastic, calculating and manipulable than they usually are" (DiMaggio, 1988: 5); and to focus on the fact that organizational actors can manipulate the symbols they present to the external

2 Within the NIS model institutions can be defined as external rules, procedures, norms, and/ or myths (Moll, et al., 2006). 
environment (Powell, 1991), as a means of reacting to external pressures. That is, organizational members do not take a passive role when reacting to external forces in choosing their own work practices (Moll, 2006 and Kholeif, et al., 2007).

The following sections explain managers' power and interests as motives for complying with external pressures. Managers use their power to create rules and legitimate strategy to improve the FRs for adhering to external pressures in order to achieve their own interests

\section{Dynamics to Create Reactive Mechanism to the External Motives}

"It is not the [case] that some organizations are constrained by the institutional environments, while others are not" (Tolbert, 1985: p2). Carpenter and Feroz (2001) argue that firms are not immutable in their responses; organizational actors respond in various ways to external pressures (Tolbert, 1985; Powell, 1991 and Modell, 2002). Even if they are operating in the same institutionalized context, organizational actors' behaviour and reactions will be highly indicative of either rejection or acceptance of such pressures (Friedland \& Alford, 1991; Oliver, 1992 ; Wickramasinghe \& Alawattage, 2007). DiMaggio (1988: 17) argues that without giving greater and more explicit concern to the organizational actors' interests and 'agency', institutional theorists will be unable to explain the reasons behind the emergence, deterioration and elimination of a particular practice.

DiMaggio and Powell (1991) voice that the necessity of taking power and interests into account emerges from the observation that, when actors in key institutions recognize that they can gain benefits from adopting and maintaining certain institutions or practices, then powerful and dominant actors can enact strategies for control. Therefore, different organizational responses are based on differences in organizations' goals, interests and usable power (Tolbert, 1985; Zucker, 1987).

From the foregoing discussion it is obvious that organizational actors' power and interests are the determinants, dynamics or motives for creating a reactive strategy to improve the FRs to comply with external environmental motives. 


\subsection{Executives' Self-interests Dynamics or Motives to Create Reactive Mechanism}

Professional self-interest is paramount when a new organizational practice is adopted and the previous one is discarded (Carpenter \& Dirsmith,1993; DiMaggio \& Powell,1991; Perrow, 1985; Powell, 1985; Scott, 1987). Shapin (1982) argues that creating knowledge or a strategy is considered as goal-directed action; it is not tailored in isolation of an individual's goals and interests but is tailored in order to "further particular collectively sustained goals".

To that effect, it is assumed that the actors/managers' behaviour and actions for adopting voluntarily preferred practice i.e. improving the FRs, are driven by the intention to serve their interests as dynamics or motives for such application (Carpenter \& Dirsmith, 1993; DiMaggio, 1988; Greenwood \& Hinings, 1996; Kholeif, et al., 2007; Soh \& Sia, 2004). This is because organizational actors are treated as producers and evaluators of knowledge to serve their own goals (Shapin, 1982). As a result, Covaleski and Dirsmith (1988) and Greenwood and Hinings (1996) suggest that, when organizational actors become dissatisfied because the adoption of a certain rule or practice does not serve their interests, this dissatisfaction leads them to question the current practice, which then causes them to make a change. That is, actors' dissatisfaction with the way in which their interests are accommodated within the firm creates a potential pressure for change.

Overall, it can be seen that organizational actors' self-interests constitute motives or dynamics for determining whether or not they create a mechanism to improve the FRs in order to comply with environmental motives e.g. outsiders and regulative bodies' requirements. However, serving such interests requires actors who have sufficient power to pursue them. Institutionalists argue that agents' ability to either support or thwart the adoption of an institutionally imposed practice is based on possessing enabling dynamics, and on the extent to which agents can mobilize sufficient power to achieve their goals and interests (Covaleski \& Dirsmith, 1988; Greenwood \& Hinings, 1996; Modell, 2002). This leads us to acknowledge that, if organizational practices and structures are shaped by organizational actors' goals and preferences, it is necessary to capture the attitudes and interests of those who have sufficient power to determine and shape such 
practices (Burns, 2000; Greenwood \& Hinings, 1996; Hussain \& Hoque, 2002).

\subsection{Organizational Actors' Power: Enabling Dynamics to Create Reactive Mechanism}

The starting point for creating certain practices to serve particular aims is the use of explicit and serious 'intervention' by active and powerful elite who aim to pursue such interests (Fligstein, 1991; Friedland \& Alford, 1991; Gouldner, 1954; Greenwood \& Hinings, 1996; Powell, 1991; Subramaniam, 2006). Meyer and Zucker (1986) argue that the extent to which forces within the institutional environment, such as suppliers and regulatory agencies, are able to penetrate a firm's boundaries is based on the firm's relative control over its own boundaries (cited in Zucker, 1987). Thus, such pressures drive powerful firms to search for or create a strategy of compromise/avoidance towards the influence of these pressures from environmental agencies on their performance (Modell, 2002 and Zucker, 1987). Pfeffer (1981) argues that organizational politics can be used as enabling (or buffering) mechanisms to respond to (or protecting from) external pressures.

In this respect, Modell (2002) contends that the compromising (or avoidance) decision rests critically on the managers' ability to evoke relatively unquestioning justifications for supporting the superiority and efficiency of the technique created, especially when it is compared with other alternatives. That is, creating an institution or strategy entails using prevailing institutional and accepted principles. As argued by DiMaggio (1988), organizational actors attempt to "harness" the institutionalized institutions to pursue their own objectives and desires. In particular, coercively imposed rules or institutions always leave space and open up possibilities for the discretion and autonomous play of interests and intervention (DiMaggio \& Powell, 1991; Friedland \& Alford, 1991; Modell, 2002; Powell, 1991; Zucker, 1987).

In this respect, managers employ their power emerging from their accounting knowledge, possessing private information about the underlying economic activities of the firm, accounting standards' flexibility, and their ability to make decisions as facilitators to choose and use either accounting actions or real business actions to be ruled-based mechanisms to improve the FRs. 


\section{Consequences of Creating Rule-based Technique}

As a result, using a rule-based mechanism strengthens the firm's legitimacy, decreases turbulence, maintains its stability, and hence mobilizes support from a broader range of external bodies. This enables the firm to enjoy support from external resource providers, gives it greater flexible access to resources, and in turn enhances its success and survival prospects (Carpenter \& Feroz, 2001; DiMaggio \& Powell, 1983; DiMaggio1988; Meyer \& Rowan, 1977; Moll, et al., 2006; Oliver, 1992). In addition, Powel (1991) argues that organizational actors tend to use rule-based actions to sustain their legitimacy, reputation, power, prestige and achieve other desired goals. That is, employing such mechanisms results in benefits not only for the firms but also for their managers.

However, firms that deviate from normal behaviour either by violating legitimate-legal rules or by generating their own unique rules for behaviour, which lack accepted legitimacy, will suffer from weak legitimacy (Meyer and Rowan, 1977; Meyer and Scott, 1983; cited in Deephouse \& Carter, 2005). Hence, the firm then needs to defend its legitimacy. One protective mechanism against the risk of illegitimacy is to dismiss or sack managers who violate the prevailing rules (e.g. financial misrepresentation) and replace them with new managers (Gilson \& Vet-suypens, 1993 and Warner et al., 1988 cited in Arthaud-Day et al., 2006). The mechanism of sacking managers is seen as a means of acceding to the demands of external factors and as a method of re-investment in reputation (Agrawal, et al., 1999; Arthaud-Day, et al., 2006). By doing so, a firm informs the most important groups of outsiders that it has made actual changes in its activities which are in accordance with what they expect from it (Lindblom, 1994 cited in Deegan, 2006 ). Therefore, dismissing culpable managers and hiring new executives with valuable reputational political capital can restore the damaged reputation and hence capital market faith in the company (Agrawal, et al., 1999; Desai, et al., 2006).

To sum up, managers use their power to create rule-based mechanisms for improving the FRs as a way of complying with the pressures exerted by external factors e.g. outsiders' whims. This enables firms to appear to be working in good faith, and increases confidence, which enhances their legitimacy and reputation with those outsiders. The consequent rise in legitimacy and reputation would result in many benefits for the firm and its 
managers: 1) increasing social support; 2) easing access to external financial and non-financial key resources; 3) enhancing and sustaining its survival in the long term; and hence 4) fulfilling managers' self- interests in terms of job security, and enhancing professional reputation, power, prestige and other monetary benefits.

\section{Research Design and Method}

Yin (2009) and Patton (2002) explained that survey is one of many qualitative methods used for collecting data. In order to fulfil the paper's purpose, semi-structured interviews are considered to be the most suitable method for collecting data. Because it allows a predetermined list of questions and to be set in advance and to use unstructured probes (Arthur \& Nazroq, 2003 ; Berg, 1995; Patton, 2002). As shown in Figure (1), the interview guide comprises both opening questions (essential or general) and probing questions, which cover the issues related to corporate executives' self-interested motives and the most important motives for managers to improve financial reports.

According to Berg (1995), in preparing the interview guide sufficient attention should be given to various issues ${ }^{3}$, including the translation of interview questions, because they are going to be used to interview respondents from another country who speak a different language. Patton (2002) argues that information gathered from interviewing is essentially words, and these words may mean various things in various cultures. Egypt is the research context, and hence more emphasis was placed on translating interview questions from English to Arabic and vice versa after the data collection and during data analysis process.

For the research sample, this paper uses the purposive sample, which is widely used in qualitative research (Ritchie et al. 2003). A purposive sample refers to the selection of the sample's units based on the researcher's experiences and judgment about the appropriate features, which are required in such units for the sake of satisfying and fulfilling the aims of the research (Patton, 2002; Ritchie, et al., 2003; Zikmund, et al., 2010). The most appropriate population's key features are determined and derived from the current research aims, the relevant literature review and the research questions and theoretical predictions. These

${ }^{3}$ Other issues include: style of questions, question sequence and wording, and the length of the interview schedule. 
characteristics are the participants' accounting knowledge and experience; their roles and professional positions as practitioners in improving FRs; and their attitudes and beliefs about such improvement. Therefore, company managers were involved as they were considered an important group to be interviewed. As shown in Table (1), this group comprises of the chairman of the board, the chief executive officer (CEO) or managing director, the financial controller, the financial manager, and the accounting manager (hereafter, executives or managers), some of whom have differing experience in commercial banks, service companies, and private and privatized firms.

Ritchie et al. (2003) assert that qualitative samples tend to be small, because data collected in qualitative research are rich in details and highly intensive resources. Table (2) shows a summary of the number and percentage of participants interviewed. A total of eleven interviewees were chosen from five different companies working in two types of fields i.e. service and industrial. Service companies and industrial companies represent $36.4 \%$ and $63.6 \%$ of the sample respectively. The three industrial companies comprised textile companies $(\mathbf{9 . 1 \%})$, pharmaceutical companies (36.3\%), and motor industrial companies $(\mathbf{1 8 . 2 \%})$, while the two service companies included tourism and hospitality companies $(9.1 \%)$, and securities brokerage companies $(27.3 \%)$.

\section{Results and Findings}

\section{Corporate Executives' Self-interests Motives}

As suggested by Carpenter and Feroz (2001), corporate executives' decisions are directed toward serving their own selfinterests. :

"Selfish behaviour has a place in management's thinking as normal human behaviour; on the whole, managerial decisions are based on selfinterests". (M9, a chairman of a board of directors)

The following sections analyse executives' opinions regarding this issue: the first section analyses executives' responses to compensation package motivations i.e. bonus and stock compensation plans; while the second section analyses executives' responses to job market incentives involving: securing their current job and enhancing their professional career. 


\subsection{Compensation Scheme Motives}

The executives' incentivizing scheme usually comprises a cash bonus (portion of profits) and stock-based plans. This scheme is normally based on the reported profit figure (Healy, et al., 1987). Therefore, Watts and Zimmerman (1978) and Dechow and Sloan (1991) argue that there is a significant association between the executives' compensation scheme and the selection of certain accounting standards. This association leads managers to select increase-earnings accounting standards in order to serve their own interests (Dechow \& Sloan, 1991; Hagerman \& Zmijewski, 1979; Watts \& Zimmerman, 1978). As a result, the compensation scheme - either the cash bonus or stock-based plan - is considered to be a motivation for managers to improve the firm's financial results. The following sections analyse executives' views about whether or not cash bonuses and stock-based plans motivate them to improve financial results.

\section{Cash Bonus Motives}

Balsam (1998), Healy (1985) and Watts and Zimmerman (1978) claim that the cash bonus is a common means of compensating executives, which establishes an association between annual reported earnings and executives' cash bonuses. This positive relationship is obvious in the Egyptian context. According to chapter one (shareholder companies) of Law No.159/19816 employees of a shareholder company have a right to receive not less than $10 \%$ of the distributed profits and not more than their annual salaries, as specified in Article (41) of the law:

"Workers in the Company shall have a share in the distributable profits to be fixed by the General Assembly on the proposal of the administrative board, at not less than $10 \%$ of these profits and not surpassing the total of the annual wages of workers in the company" (emphasis added).

This association motivates executives to improve the annual earnings figures by selecting income-increasing accounting standards (Balsam, 1998; Bange \& De Bondt, 1998; Bowen, et al., 1995; Dechow \& Sloan, 1991; Watts \& Zimmerman, 1978).

Analysing executives' views revealed that there is general agreement on this issue in stating that a profit-based cash bonus is

${ }^{4}$ Law No.159/1981 on Joint Stock Companies, Partnerships Limited By Shares \& Limited liability Companies As Amended By Laws N0s. 212/1994, 3/1998 And 159/1998. 
an important factor that motivates them to improve their firm's performance and to report increases in profits:

"Increasing cash bonus is an important factor for the employees, which encourages them to increase profits... if a manager reports abnormal profits, he must have a large part of the cake [i.e. large share of such profits]..."(M2, an accounting manager).

Executives also highlight that profit maximization is the main target of the firm's owners and that managers are their agents, so that increasing the firm's profits is the responsibility of the managers, who must be compensated for doing so:

"Profits or profit maximization is the aim of shareholders, and managers are the agents of the shareholders to achieve such aim for them; this also benefits the firm's managers in terms of getting a distribution percentage from such profits" (M10, a financial manager).

\section{Stock-based Compensation Plan Motives}

Dechow and Skinner (2000) argue that, over the last two decades, there has been increasing emphasis on stock-based compensation contracts as a motivation for EM, because this kind of management compensation increasingly couples top managers' wealth with the firm's stock price.

Importantly, under Egyptian company law, there is no opportunity to compensate firms' executives by stocks. Thus, the stock-compensation plan has no effect on a firm's managers' intention to improve the firm's financial position in the Egyptian context. Therefore, executives are not too concerned with stockbased compensation as a motive for improving the reported earnings because they view acquiring stock as the least important of their aims, as expressed in the following comments:

"At the end of my objective list is gaining some of the firm's stocks" (M1, a financial manager). "For me the last motive for improving the firm's financial report is seeking to get the firm's stocks" (M2, a accounting manager).

\subsection{Job Market Motives}

Besides the executives' compensation scheme, the labour market is another influential factor motivating managers to improve financial reports. This motivation can be further divided into two types: securing the current job; and improving the professional career and reputation. Analysis of the executives' responses to 
questions about job market motivations is presented in the following sections.

\section{Job Security Motives}

As argued by Degeorge et al. (1999), the association between reported earnings and job preservation induces a firm's managers to improve their financial results. Thus, securing their current job or avoiding dismissal is a motivation for improving the published profits figure (DeAngelo, et al., 1994; Pourciau, 1993). From the executives' responses, it can be clearly seen that there is general agreement regarding this issue, as executives believe in the importance of improving the financial image of the firm to secure their own jobs. The following quote summarizes the executives' beliefs:

"Firm's owners need profits as the main aim of any private company; in the case of reporting losses the financial manager, the managing director or/and the chairman of the board of directors will fly. This increases managers' emphasis on the financial results of the company to protect their jobs" (M10, a financial manager, emphasis added).

Executives believe that improving the firm's financial image by creating profits leads to shareholder satisfaction because profit maximisation is their main aim, and without the owners' satisfaction they cannot secure their own jobs. That is, if the managers fail to achieve the owners' main aim (profits), they will definitely lose their jobs, as a financial manager (M10) explains:

"Profits or profit maximization is the aim of shareholders... achieving the owners' aim means keeping their jobs".

This belief is based on the grounds that the managers are the agents of the firm's owners and is responsible for adopting the best policies and making effective decisions for running the firm successfully and for achieving favourable outcomes by using their experience. Thus, executives believe that, based on the firm's operational performance, the general assembly of shareholders (GAS) determines whether they still trust the current managers and whether they are satisfied with its achievements, and in turn influences their decision about whether or not to keep the existing managers. Undesirable financial results lead to a loss of shareholder trust in the firm's managers, which in turn leads them to replace current managers with new managers capable of achieving better results: 
"Top management is the party which is directly affected by the reported financial and operational results. Because top executives are responsible for making the operational decisions, the results of those decisions are the bases used by the general assembly of shareholders to make decisions regarding whether they renew their trust in top managers or not... For the top management the most important motivation to avoid undesirable results is protecting their current job because bad operational results lead to a loss of investors' trust in management's work and hence they will not renew current managers' contracts and they will lose their jobs" (M2, an accounting manager, emphasis added).

However, executives believe that not all cases of reporting losses will lead them to lose their jobs; they expressed the view that the likelihood of losing their job depends on whether or not there are logical reasons justifying the unfavourable operational performance of the firm. When GAS finds out why executives remained silent and did not make decisions to improve the operational results of the firm, they decide whether or not managers should be replaced. If losses were due to certain environmental factors, e.g. political and economic factors, this does not have any negative effect on managers' jobs:

"Management will be questioned about reporting losses...owners will ask you why you did not take actions to avoid losses; why you remained silent when the company lost money; the answers to those questions affect your ability to stay in your position" (M10, a financial manager).

"In the case of losses which are achieved under common and normal conditions I will lose my job. However, if the losses are achieved under abnormal conditions like what is happening nowadays [Egyptian revolution], nobody can say that the managers (or the board of directors) of a company which reports losses will be dismissed" (M6, a financial manager).

Executives believe that the field in which a firm operates has an effect on concerns about their jobs; the executives of brokerage companies drew a significant link between achieving desirable financial results and maintaining their jobs. The executives of brokerage companies appeared to believe that the turnover in their field is very high so that an unfavourable performance will definitely result in the loss of their jobs. This makes them very anxious about keeping their jobs, as the following comment from managing director (M8) illustrates: 
“... Keeping a top management job is a prime factor leading executives to improve the financial reports, especially in our field [brokerage] where the labour turnover is very high ... there is strong and sensitive relation between achieving good results and keeping my job. Of course, in this field, there are great concerns about my job in a company which achieves undesirable results i.e. losses".

\section{Professional Reputation and Career Motives}

Corporate executives are motivated to gain a high professional reputation in order to improve the possibility of getting a better job in the future (Subramaniam, 2006). Fama and Jensen (1983) argue that executives' reputations and human capital values are enhanced on the basis of their performance. Based on Subramaniam's (2006) and Fama and Jensen's (1983) argument, enhancing the professional reputation and career can be considered as motives for the firm's managers to improve their performance i.e. reporting profits.

All executives share the same view on this issue, and believe that the managers' ability to achieve a better performance and improve the financial image of the firm reflects its effectiveness and success, which in turn boosts their reputation in the job market:

'Improving the firm's results is a measure of the managers' success, which yields other benefits like better reputation. When I succeed in changing the position of a firm from negative to positive; this reflects my effectiveness in running the company which enhances my professional reputation in the field because $I$ alter its financial image from a low status to the opposite one" (M8, a managing director).

In addition, executives believe that an improved professional reputation, which is built on their previous performance, makes them highly sought after in the job market, and enables them to get a better job more easily in the future. They consider a good professional reputation as a form of wealth, which they can use and invest at any time when required:

"I seek to create a better reputation in my field to enable me to move to another company at any time. I will have an enhanced reputation, which encourages other companies in my field to favour and want me to work for them... This good reputation will be my treasury and wealth, which I can invest whenever I like" (M3, a financial controller).

Executives expressed the view that gaining high monetary returns from their work is not an object per se, but that those high returns 
reflect the fact that they are highly valued human capital and highly reputed professionals, due to their effectiveness and success:

"Doubtless, earning high salaries and cash bonuses is not an aim per se but it is a title and an indicator that I am highly evaluated ... the more salary I earn, the more success I achieved. The more success I achieved, the higher valuation I get" (M9, a chairman of the board of directors).

As well as reputation, their professional career is another motive for improving the financial image of a firm. All the executives of various ages associated an individual's professional career with their ambition to look for better positions, which thereby motivates them to confirm their success and effectiveness by improving the firm's financial image. They stated that, if there is no ambition, there will not be any motivation to look for better career prospects and in turn to achieve success and financial improvement. An analysis of the executives' responses reveals clear-cut agreement that, in Egypt, a young person at the beginning of his career does not always occupy a very high position, so that he/she is ambitious and significantly motivated to seek out better opportunities, and hence to build and improve his career. So that managers at the beginning of their career are motivated to make financial improvements, which help them to achieve success, to enhance their reputation, to seek more advanced positions, and hence to build their career or curriculum vitae (CV) as a professional:

"For me, ambition and looking forward to better prospects e.g. better job, reputation, salary and career are my motives for making decisions designed to increase profits...If there is no ambition and desire for improvement, there will be no motives for me" (M3, a financial controller, 38 years old).

"In Egypt, young people at the beginning of their professional career; do not occupy high positions, so that a person at the beginning of his career is more willing to improve the financial image of the firm to improve his position (M11, CEO), 59 years old).

Importantly, a financial manager (M5) stated "... The person at the end of his career does not have such ambition to improve the financial reports because he is going to leave the job market".

However, other executives believe that an individual at the end of his career is motivated to improve a firm's financial image in order to maintain his/her good professional history and previous 
career reputation, which they have succeeded in building up over their professional history.

"... A person in the last years of his career likes to keep his reputation and professional image, which he has built over his whole professional life. A good career history, which he succeeded in creating over 20-30 years, he will not be willing to jeopardise it in the last years of his career by reporting undesirable financial results " (M7, a financial manager).

\section{Comparison Between Different Managerial Motives}

This section focuses on the second purpose of the paper; it analyzes the executives' views to provide evidence about whether external motives or managers' self-interested motives are considered the most important incentives for improving the FRs, and whether monetary or non-monetary issues constitute the most significant inducements for doing so.

\subsection{Comparison Between Outside Parties Motives and Executives' Self-interests Motives}

As argued by Bergstresser and Philippon (2006), executives may manipulate earnings in order to game the capital market and, more generally, to influence outsiders' perceptions of the firm's future affairs so as to serve their own self-interests. When asked their views on whether pressure from outsiders or their own selfinterests are the strongest motivational factors shaping their behaviour to improve financial results, in general they are quick to assert that both factors are "one package" and they are "two sides of one coin:

"All those motivations are one package; it is difficult to separate between them" (M11, a chief executive officer (CEO)).

"There are no clear cut boundaries between the firm's interests e.g. success and reputation with its outsiders and managers' self-interests e.g. success and reputation, they are two faces of one coin" (M10, a financial manager).

Importantly, they believe that building, maintaining and improving the outside parties' long-term-trust in the company are the bases and the cornerstone from which they must start to achieve their own self-interests, as expressed in the following comment:

"My firm's stability and achieving its targets and interests are the basic step in achieving my own targets. I can pursue my self-interests through 
achieving the firm's interest... I seek to achieve the firm's targets first, and consequently I start determining and achieving my own targets" (M3, a financial controller).

The executives emphasized the strong relationship between the firm's success and reputation and their own success and professional reputation. They believed that the firm's good reputation and strong relations with relevant outsiders reflects positively on the managers' interests i.e. professional reputation, which has a favourable influence on managers' ability to keep their jobs.

"My main duty and the most important part of my responsibility are protecting and enhancing my firm's financial image and reputation, which is the basis of my own reputation" (M5, a financial manager).

"Enhancing outsiders' trust in my company is more important than seeking to pursue my own interests; if I gained outsiders' trust in my company, logically I would protect my professional position in the company" (M1, a financial manager).

Importantly, one financial manager (M7) claimed that "improving the firm's image in outsiders' eyes must be the first priority of the managers' concern, followed by other lesser priorities e.g. keeping the job and the like".

In addition, the executives asserted that unless they coping with the firm's peers in the field by reporting a comparable earnings level, they are in danger of losing their jobs. This is because managers' failure to cope with other firms will be perceived as reflecting its ineffectiveness and thus seen as abortive management, as explained by the following executive:

"... If all companies in the field achieve good financial results and my company do not... this reflects the managers' failure ... When other firms except our managers achieve good results, this means that it is unsuccessful or abortive management... In this case, I must take care because I will be fired" (M6, a financial manager).

The executives felt that placing more short-run emphasis on their self-interests and ignoring the firm's interests and its reputation with outsiders in the long-run would lead to failure for the firm and its managers. Ignoring the firm's reputation and relationship with outsiders in the long-term would lead to the destruction of what managers had previously built up and gained for itself, as expressed by the following respondent: 
"Of course, enhancing the firm's interests in terms of enhancing its reputation with outsiders is the more powerful factor for me to improve the financial image of my firm; a person may mistakenly think that his self-interests are more important than firm's the interests. Managers' self-interests are temporary and short-term. If I focused on my selfinterests and placed them before the firm's interests, I would lose mine" (M9, a chairman of the board of directors).

\subsection{Comparison Between Managerial Self-interests Motives: Monetary and Non-monetary}

As shown above, managers' self- interests comprise monetary interests, i.e. cash bonus, and non-monetary interests, i.e. job security and professional career and reputation. As suggested by Indjejikian (1999), implicit incentives such as career image and reputation are favoured more by executives relative to explicit incentives e.g. monetary factors, when choosing or adopting a particular practice.

Closer scrutiny of their responses indicates that the majority of executives felt that job market motives are more important than monetary motivations. The executives believed that there is a mutual relationship between job security and professional reputation; they can enhance each other. They also saw job security or professional reputation as a basic tool with which to acquire monetary returns and other non-monetary benefits.

Regarding the importance of job security, the executives thought that, if they lost their employment, they would lose their salary and reputation, i.e. lose both cash and non-cash advantages.

"Securing my job is the basis of getting other things. If I failed to keep my job and lost my salary how I could I earn more cash bonus, enhance my reputation and the like" (M6, a financial manager).

"Every benefit is linked to others. Promotion, reputation, professional career and cash incentives are born from securing my job. I cannot get promotion or be compensated with other cash or non- cash incentives unless I can maintain my employment" (M7, a financial manager).

As for the importance of the professional reputation, the executives view building up and improving their professional reputation, which is based on their efficiency and ability to succeed the firm is a basic way of keeping their jobs. Building up a good reputation will result in gaining more reputation, hence 
remaining in employment, and enjoying additional kinds of incentives, including increased cash advantages.

"... Achieving better financial results enhances my reputation, because I am able to change the firm's financial results from losses to profits, hence this means that I can keep my job and that I must be compensated with cash returns" (M8, a managing director).

Surprisingly, perhaps, none of those interviewed mentioned that monetary factors such as high salaries or cash bonuses can yield moral and non-monetary benefits e.g. job security, better professional reputation and career opportunities.

\section{Discussion and Conclusion}

The first aim of this paper is to present empirical evidence consistent with theoretical suggestions about managers' ability to react to those external motives by using their power in order to serve their own interests. Those interests are influenced by the context in which managers work. It is deduced that, in the Egyptian context, three out of the four factors considered as selfmanagerial motives have a highly influential effect on managers' propensity to improve the FRs; however, the fourth factor has no motivational influence at all.

The first motivational factor is the cash bonus, which is considered as an influential component of the executives' compensation scheme on managers' behaviour. In accordance with Egyptian laws, which determine the compensation scheme for employees, it is deduced that the cash bonus $(10 \%$ percent of the company's profits) has a great influence on the managers' intention to improve its performance and to report increases in profit number.

The second motivational factor is job security. This is seen as a very important motive for corporate management to take into account the results of its operational decisions. Because reporting financial losses resulting from managers' ineffective and poor operational decisions, rather than from abnormal environmental factors e.g. political and/or economic issues, leads to dissatisfaction among the firm owners' with management performance, this in turn threatens managerial jobs. Interestingly, the executives highlighted that the nature of the firm's business affects the extent of managers' concerns about the threat to their jobs. In certain fields - such as brokerage - there is a high turnover of employees, which motivates executives to place more 
emphasis on the firm's financial results in order to maintain their jobs; this greater concern is due to the sensitive relation between reporting losses and the threat to their jobs.

The third motivational factor is the managers' professional reputation and career. Building up a good professional reputation in the job market is considered as an important motive for managers to confirm their effectiveness and success in order to become a highly valued human resource; thus, improving the firm's financial image is a way helping them to do so. For managers, their professional reputation is viewed as a form of wealth, which enables them to get a better job in the future when needed. Moreover, professional career is another motive for improving the financial reports. Seeking to improve a firm's financial image for the sake of bettering themselves and enhancing their status and prestige, i.e. gaining a better reputation, job and position, is influenced by which stage a manager is at in his/her career. A person at the beginning of his/her career is motivated and ambitious to improve the firm's financial image to ensure his/her success, and hence to building his/her career. The opposite holds true for executives at the end of their career. However, it is argued that managers who are close to leaving the job market are still motivated to achieve success and to make financial improvements in order to maintain their good professional history.

The fourth potential motivational or influential factor is the stockcompensation plan. However, in the Egyptian context, the stockcompensation plan as a way to compensate executives has no effect on managerial motivations to improve the firm's financial position, because such schemes do not exist. This result is in contrast with Bens et al.'s (2002) and Cheng's (2004) findings whose research was conducted in other contexts.

Thus, the effect of the executives' compensation plan as an economic motive depends on the context of the study, because it is determined and defined in accordance with company laws, which differ among countries.

The second aim of this paper is to compare external motives and motives of managerial self-interest in accordance with their importance. In the Egyptian context there are two kinds of factors which act as motivations for managers to improve financial results and report favourable results: motives exerted by other 
firms and bodies which exist in the firm's external context; and managers' self-interested motivations.

The comparison highlights that external motives (i.e. financial suppliers, regulatory bodies, other stakeholders, economic system, managers' beliefs, beating the common earnings target in the field and managers' characteristics and beliefs) go hand in hand with managers' self-interests (i.e. cash bonus, job security and enhancing professional reputation and career); together they form a package of incentives for improving financial results. It has been clearly evidenced that self-interests cannot be gained at the expense of external motives. That is, it is impossible to secure one's own job and to gain professional reputation without establishing a highly-reputed, economically fit and legitimate firm in its context. It is found that a firm's success and interests is the basis of its managers' success and benefits, and that focusing on the executives' self-interests and neglecting the firms' interests is a short-term and temporary aim, which leads to failure for both the firm and its management. It is worth noting that the hierarchy of managerial motives for improving a firm's financial results shows that executives place external environmental factors at the top of the pyramid, as more influential and motivational than selfinterested factors. Those external motivations are followed by executives' self- interests in terms of their importance.

Furthermore, this paper compares the two components of managerial self-interests; when factors of managerial self-interest are ordered hierarchically, non-cash motives, i.e. securing the current job and professional reputation, occupy the top of such a hierarchy, followed by monetary motives i.e. cash bonus. It has been clearly evidenced that job market motives are considered more important incentives for improving the FRs than cash bonuses, because job market motives are the basis of getting cash compensations, and not the opposite. This is consistent with Graham et al.'s (2005) research, which cites evidence based on interviewing executives that job security and career image play a more important role in motivating managers to manipulate earnings than compensation incentives.

The empirical findings of this paper contribute to the existing literature concerning EM motivations by casting light on new areas, which have previously been given little -if any- attention, including: 1) Managerial self-interested motives in the Egyptian 
context for improving the FRs; 2) The influence of the firm's context on determining the companies' regulatory laws, which define the executives' compensation scheme and hence on shaping managers' self-interests; 3) The diversity of managerial incentives; managers are motivated by a package of motives; 4) The relationship between different kinds of managerial motivations and the hierarchical order of such motives in accordance with their importance for executives; 5) The influence of the nature of firm's activity on strengthening the impact of a motive; 6) On the theoretical level, this paper seeks to strengthen the analytical framework of NIS, by overcoming its defaults by taking into account the power and interests of organizational actors as two dynamics for reacting to external pressures or motives.

\section{References}

Abdel-Khalik, A. R. (1985). The Effect of LIFO-Switching and Firm Ownership on Executives' Pay. Journal of Accounting Research, 23(2), 427-447.

Agrawal， A., Jaffe, Jeffreŷ̂A F., \& Karpoff, JonathanÂA M. (1999). Management Turnover and Corporate Governance Changes following the Revelation of Fraud. Journal of Law and Economics, 42(S1), 309-342.

Arthaud-Day, M. L., Certo, S. T., Dalton, C. M. D., \& Dalton, D. R. (2006). A Changing of the Guard: Executive and Director Turnover Following Corporate Financial Restatements Academy of Management Journal, 49(6), 1119-1136.

Arthur, S., \& Nazroq, J. (2003 ). Desinging Fieldwork Strategies and Materials In J. Ritchie \& J. Lewis (Eds.), Qualitative Research Practice: A Guide for Social Science Students and Researchers (pp. 110-137): London: SAGE.

Balsam, S. (1998). Discretionary Accounting Choices and CEO Compensation. Contemporary Accounting Research, 15(3), 229-252. 
Bange, M., \& De Bondt, W. (1998). R\&D budgets and corporate earnings targets. Journal of Corporate Finance, 4(2), 153-184.

Barley, S. R., \& Tolbert, P. S. (1997). Institutionalization and Structuration: Studying the Links Between Action and Institution. Organization Studies (Walter de Gruyter GmbH \& Co. KG.), $18(1), 93$.

Bartov, E., Givoly, D., \& Hayn, C. (2002). The Rewards to Meeting or Beating Earnings Expectations. Journal of Accounting and Economics, 33(2), 173-204.

Bartov, E., \& Mohanram, P. (2004). Private Information, Earnings Manipulations, and Executive Stock-Option Exercises. Accounting Review, 79(4), 889-920.

Beneish, M. D. (1999 a). Incentives and Penalties Related to Earnings Overstatements That Violate GAAP. The Accounting Review, 74(4), 425-457.

Beneish, M. D., Press, E. G., \& Vargus, M. E. (2001). The Relation Between Incentives to Avoid Debt Covenant Default and Insider Trading. Unpublished Working Paper. Indiana University.

Beneish, M. D., \& Vargus, M. E. (2002). Insider Trading, Earnings Quality, and Accrual Mispricing. Accounting Review, 77(4), 755-791.

Berg, B. (1995). A Dramaturgical Look at Interviewing. In B. berg (Ed.), Qualitative Research Methods for Social Sciences (pp. 66-110): Needham Heights, Mass: Allyn \& Bacon

Bergstresser, D., \& Philippon, T. (2006). CEO Incentives and Earnings Management. Journal of Financial Economics, 80(3), 511-529.

Bowen, R. M., DuCharme, L., \& Shores, D. (1995). Stakeholders' Implicit Claims and Accounting Method Choice. Journal of Accounting and Economics, 20(3), 255-295.

Brint, S., \& Karabel, J. (1991). Institutional Origins and Transformations: The Case of American Community Colleges. In W. Powell \& P. DiMaggio (Eds.), The New Institutionalism in 
Organizational Analysis (pp. 337-360): Chicago: University of Chicago Press.

Burgstahler, D., \& Eames, M. (2003). Earnings Management to Avoid Losses and Earnings Decrease: Are Analysts Fooled? Contemporary Accounting Research, 20(2), 253-294.

Burns, J. (2000). The Dynamics of Accounting Change: Inter-play between New Practices, Routines, Institutions, Power and Politics. Accounting, Auditing \& Accountability Journal, 13(5), 566-596.

Burns, J., \& Scapens, R. (2000). Conceptualizing Management Accounting Change: An Institutional Framework. Management Accounting Research, 11(1), 3-25.

Burns, N., \& Kedia, S. (2006). The Impact of Performance-based Compensation on Misreporting. Journal of Financial Economics, 79(1), 35-67.

Bushee, B. J. (1998). The Influence of Institutional Investors in Myopic R\&D Investment Behavior. Accounting Review, 73(3), 305.

Carpenter, B., \& Dirsmith, M. (1993). Sampling and the abstraction of knowledge in the auditing profession: An extended institutional theory perspective. Accounting, Organizations and Society, 18(1), 4163.

Carpenter, V., \& Feroz, E. (2001). Institutional Theory and Accounting Rule Choice: An Analysis of Four US State Governments' Decisions to Adopt Generally Accepted Accounting Principles. Accounting,Organizations and Society, 26(7-8), 565-596.

Carruthers, B. G. (1995). Accounting, ambiguity, and the new institutionalism. Accounting, Organizations and Society, 20(4), 313328.

Cheng, Q., \& Warfield, T. (2005). Equity Incentives and Earnings Management. The Accounting Review, 80(2), 441-476. 
Cheng, S. (2004). R\&D Expenditures and CEO Compensation. The Accounting Review, 79(2), 305-328.

Collier, P. (2001). The Power of Accounting: A Field Study of Local Financial Management in a Police Force. Management Accounting Research, 12(4), 465-486.

Covaleski, M. A., \& Dirsmith, M. W. (1988). An Institutional Perspective on the Rise, Social Transformation, and Fall of a University Budget Category. Administrative Science Quarterly, 33(4), 562-587.

Crocker, K. J., \& Slemrod, J. (2007). The Economics of Earnings Manipulation and Managerial Compensation. The RAND Journal of Economics, 38(3), 698-713.

DeAngelo, H., DeAngelo, L., \& Skinner, D. J. (1994). Accounting Choice in Troubled Companies. Journal of Accounting and Economics, 17(12), 113-143.

Dechow, P., \& Skinner, D. (2000). Earnings Management: Reconciling the Views of Accounting Academics, Practitioners, and regulators. Accounting Horizons, 14(2), 235-250.

Dechow, P., \& Sloan, R. (1991). Executive Incentives and the Horizon Problem: An Empirical Investigation. Journal of Accounting and Economics, 14(1), 51-89.

Deegan, C. (2006 ). Legitimacy Theory In Z. Hoque (Ed.), Methodological Issues in Accounting Research : Theories, Methods and Issues: London: Spiramus Press.

Deephouse, D. L., \& Carter, S. M. (2005). An Examination of Differences Between Organizational Legitimacy and Organizational Reputation. Journal of Management Studies, 42(2), 329-360.

DeFond, M. L., \& Park, C. W. (1997). Smoothing income in anticipation of future earnings. Journal of Accounting and Economics, 23(2), 115139. 
Degeorge, F., Patel, J., \& Zeckhauser, R. (1999). Earnings Management to Exceed Thresholds*. The Journal of Business, 72(1), 1-33.

Desai, H., Hogan, C. E., \& Wilkins, M. S. (2006). The Reputational Penalty for Aggressive Accounting: Earnings Restatements and Management Turnover. Accounting Review, 81(1), 83-112.

DiMaggio, \& Powell, W. (1983). The Iron Cage Revisited: Institutional Isomorphism and Collective Rationality in Organizational Fields. American Sociological Review, 48(2), 147-160.

DiMaggio, P. (1988). Interest and Agency in Institutional Theory. In L. Zucker (Ed.), Institutional Patterns and Organizations: Culture and Environment. (pp. 3-21): Cambridge, MA: Ballinger.

DiMaggio, P., \& Powell, W. (1991). Introduction In W. Powell \& P. DiMaggio (Eds.), The New Institutionalism in Organizational Analysis (pp. 1-38): Chicago: University of Chicago Press.

Doupnik, T., \& Richter, M. (2003). Interpretation of Uncertainty Expressions: a Cross-national Study. Accounting, Organizations and Society, 28(1), 15-35.

Fama, E. F., \& Jensen, M. C. (1983). Separation of Ownership and Control. Journal of Law and Economics, 26(2), 301-325.

Feroz, E. H., Park, K., \& Pastena, V. S. (1991). The Financial and Market Effects of the SEC's Accounting and Auditing Enforcement Releases. Journal of Accounting Research, 29, 107-142.

Fligstein, N. (1991). The Structural Transformation of American Industry : An Institutional Account of the Causes of Diversification in the Largest Firms, 1919-1979. In W. Powell \& P. DiMaggio (Eds.), The New Institutionalism in Organizational Analysis (pp. 311-336): Chicago: University of Chicago Press

Francis, J., Huang, A. H., Rajgopal, S., \& Zang, A. Y. (2008). CEO Reputation and Earnings Quality. Contemporary Accounting Research, 25(1), 109-147. 
Friedland, R., \& Alford, R. (1991). Bringing Society Back in: Symbols, Practices, and Institutional Contradictions. In W. Powell \& P. DiMaggio (Eds.), The New Institutionalism in Organizational Analysis (pp. 232-263): Chicago: University of Chicago Press

Gilson, S. C. (1989). Management turnover and financial distress. Journal of Financial Economics, 25(2), 241-262.

Gilson, S. C., \& Vetsuypens, M. R. (1993). CEO Compensation in Financially Distressed Firms: An Empirical Analysis. Journal of Finance, 48(2), 425-458.

Gouldner, A. (1954). Patterns of Industrial Bureaucracy: New York: Free Press of Glencoe.

Graham, R., Harvey, R., \& Rajgopal, S. (2005). The Economic Implications of Corporate Financial Reporting. Journal of Accounting and Economics, 40(1-3), 3-73.

Granovetter, M. (1985). Economic Action and Social Structure: The Problem of Embeddedness American Journal of Sociology 91(3), 481-510.

Gray, S. J. (1988). Towards a Theory of Cultural on the Development of Accounting Influence Systems Internationally. Abacus, 24(1), 1-15.

Greenwood, R., \& Hinings, C. (1996). Understanding Radical Organizational Change: Bringing together the Old and the New Institutionalism. The Academy of Management Review, 21(4), 10221054.

Gunny, K. A. (2010). The Relation Between Earnings Management Using Real Activities Manipulation and Future Performance: Evidence from Meeting Earnings Benchmarks. Contemporary Accounting Research, 27(3), 855-888. 
Hagerman, R. L., \& Zmijewski, M. E. (1979). Some Economic Determinants of Accounting Policy Choice. Journal of Accounting and Economics, 1(2), 141-161.

Healy, P. M. (1985). The Effect of Bonus Schemes on Accounting Decisions. Journal of Accounting and Economics, 7(1-3), 85-107.

Healy, P. M., Kang, S.-H., \& Palepu, K. G. (1987). The Effect of Accounting Procedure Changes on CEOs' Cash Salary and Bonus Compensation. Journal of Accounting and Economics, 9(1), 7-34.

Hopwood, A. G. (1987). The Archeology of Accounting Systems. Accounting, Organizations and Society, 12(3), 207-234.

Hussain, M., \& Hoque, Z. (2002). Understanding non-financial performance measurement practices in Japanese banks. Accounting, Auditing \& Accountability Journal, 15(2), 162-183.

Indjejikian, R. J. (1999). Performance Evaluation and Compensation Research: An Agency Perspective. Accounting Horizons, 13(2), 147. 157.

Karpoff, J. M., Scott Lee, D., \& Martin, G. S. (2008 b). The Consequences to Managers for Financial Misrepresentation. Journal of Financial Economics, 88(2), 193-215.

Kedia, S., \& Philippon, T. (2009). The Economics of Fraudulent Accounting. The Review of Financial Studies 22(6), 2169-2199.

Kholeif, A., Abdel-Kader, M., \& Sherer, M. (2007). ERP Customization Failure: Institutionalized Accounting Practices, Power Relations and Market Forces. Journal of Accounting and Organizational Change, 3(3), 250-269.

Matsunaga, S. R., \& Park, C. W. (2001). The Effect of Missing a Quarterly Earnings Benchmark on the CEO's Annual Bonus. Accounting Review, 76(3), 313.

Makhaiel, N., K., \& Sherer, J.,M, (2017) " In the Name of Others: An Investigation of Earnings Management Motives in Egypt" Journal of 
Accounting in Emerging Economies, Vol. 7 No. 1, pp.1-29

Meyer, J. W., \& Rowan, B. (1977). Institutionalized Organizations: Formal Structure as Myth and Ceremony. The American Journal of Sociology, 83(2), 340-363.

Modell, S. (2002). Institutional perspectives on cost allocations: integration and extension. European Accounting Review, 11(4), 653679.

Moll, J., Burns, J., \& Major, M. (2006). Institutional Theory In Z. Hoque (Ed.), Methodological Issues in Accounting Research : Theories, Methods and Issues: London: Spiramus Press.

Moses, O. D. (1987). Income Smoothing and Incentives: Empirical Tests Using Accounting Changes. Accounting Review, 62(2), 358.

Oliver, C. (1992). The antecedents of deinstitutionalization. Organization studies, 13(4), 563.

Patton, M. (2002). Qualitative Research and Evaluation Methods: Thousand Oaks, Calif.: Sage

Perera, M. (1989 a). Towards a Framework to Analyze the Impact of Culture on Accounting. The International Journal of Accounting, 24(1), 42-56.

Pergola, T. M. (2005). Management Entrenchment: Can It Negate the Effectiveness of Recently Legislated Governance Reform? Journal of American Academy of Business, Cambridge, 6(2), 177-183.

Perrow, C. (1985). Review: Overboard with Myth and Symbols. The American Journal of Sociology, 91(1), 151-155.

Pfeffer, J. (1981). Power in organizations: Marshfield, Mass. : Pitman Pub.

Pourciau, S. (1993). Earnings Management and Nonroutine Executive Changes. Journal of Accounting and Economics, 16(1-3), 317-336.

Powell, W. (1985). Review: The Institutionalization of Rational Organization. Contemporary Sociology, 14(5), 564-566. 
Powell, W. (1991). Expanding the Scope of Institutional Analysis In W. Powell \& P. DiMaggio (Eds.), The New Institutionalism in Organizational Analysis (pp. 183-203): Chicago: University of Chicago Press.

Rezaee, Z. (2005). Causes, Consequences, and Deterence of Financial Statement Fraud. Critical Perspectives on Accounting, 16(3), 277-298.

Ritchie, J., Lewis, J., \& Elam, G. (2003). Designing and Selecting Samples. In J. Ritchie \& J. Lewis (Eds.), Qualitative Research Practice: A Guide for Social Science Students and Researchers (pp. 77-108): London: Sage.

Scapens, R., \& Roberts, J. (1993). Accounting and Control: A Case Study of Resistance to Accounting Change. Management Accounting Research, 4(1), 1-32.

Scott, W. (1987). The Adolescence of Institutional Theory. Administrative Science Quarterly, 32(4), 493-511.

Shapin, S. (1982). History of Science and its Sociological Reconstructions. History of Science p.157-211.

Smith, C. W., \& Watts, R. L. (1982). Incentive and Tax Effects of Executive Compensation Plans Australian Journal of Management, $7(2), 139$.

Soh, C., \& Sia, S. K. (2004). An institutional perspective on sources of ERP package-organisation misalignments. The Journal of Strategic Information Systems, 13(4), 375-397.

Subramaniam, N. (2006). Agency Theory and Accounting Research: An Overview of Some Conceptual and Empirical Issues In Z. Hoque (Ed.), Methodological Issues in Accounting Research: Theories, Methods and Issues: London: Spiramus Press

Tolbert, S. (1985). Institutional Environments and Resource Dependence: Sources of Administrative Structure in Institutions of Higher Education. Administrative Science Quarterly, 30(1), 1-13. 
Tsamenyi, M., Cullen, J., \& González, J. (2006). Changes in Accounting and Financial Information System in a Spanish Electricity Company: A New Institutional Theory Analysis. Management Accounting Research, 17(4), 409-432.

Watts, R. L., \& Zimmerman, J. L. (1978). Towards a Positive Theory of the Determination of Accounting Standards. The Accounting Review, 53(1), 112-134.

Watts, R. L., \& Zimmerman, J. L. (1990). Positive Accounting Theory: A Ten Year Perspective. Accounting Review, 65(1), 131-156.

Weisbach, M. S. (1988). Outside Directors and CEO Turnover. Journal of Financial Economics, 20, 431-460.

Wickramasinghe, D., \& Alawattage, C. (2007). Management accounting change : approaches and perspectives: London : Routledge.

Yin, R. (2009). Case Study Research: Design and Methods: Los Angeles, Calif.: Sage Publications.

Zikmund, W., Babin, B., Carr, J., \& Griffin, M. (2010). Business Research Methods: Mason, $\mathrm{OH}$ : South-Western.

Zucker, L. (1987). Institutional Theories of Organization. Annual Review of Sociology, 13, 443-464. 
Table 1 Demography of Corporate Executives

\begin{tabular}{|c|c|c|c|c|c|}
\hline$\underline{\text { No }}$ & Position & $\underline{\text { Age }}$ & Experience & Certificate & Company \\
\hline M1 & $\begin{array}{l}\text { financial } \\
\text { manager }\end{array}$ & 42 & 12 & $\begin{array}{l}\text { Diploma in } \\
\text { accounting and } \\
\text { audit study }\end{array}$ & $\begin{array}{l}\text { Pharmaceutical } \\
\text { industrial company }\end{array}$ \\
\hline M2 & $\begin{array}{l}\text { Accounting } \\
\text { manager }\end{array}$ & 37 & 9 & $\begin{array}{l}\text { Diploma in } \\
\text { accounting and } \\
\text { audit study }\end{array}$ & $\begin{array}{l}\text { Pharmaceutical } \\
\text { industrial company }\end{array}$ \\
\hline M3 & $\begin{array}{l}\text { Financial } \\
\text { controller }\end{array}$ & 38 & 16 & $\begin{array}{l}\text { Master business } \\
\text { administration } \\
\text { (MBA) }\end{array}$ & $\begin{array}{l}\text { Car industrial } \\
\text { company }\end{array}$ \\
\hline M4 & $\begin{array}{l}\text { Financial } \\
\text { manager }\end{array}$ & 33 & $\mathbf{1 0}$ & MBA & $\begin{array}{l}\text { Car industrial } \\
\text { company }\end{array}$ \\
\hline M5 & $\begin{array}{l}\text { Financial } \\
\text { manager }\end{array}$ & 50 & 25 & MBA & Textile co \\
\hline M6 & $\begin{array}{l}\text { financial } \\
\text { manager }\end{array}$ & 42 & 20 & $\begin{array}{l}\text { Diploma in } \\
\text { accounting and } \\
\text { audit }\end{array}$ & $\begin{array}{l}\text { hospitality and } \\
\text { restaurants }\end{array}$ \\
\hline M7 & $\begin{array}{l}\text { Financial } \\
\text { managers }\end{array}$ & 28 & 6 & (MBA) & brokerage company \\
\hline M8 & $\begin{array}{l}\text { Managing } \\
\text { Director }\end{array}$ & 60 & $\begin{array}{l}41 \text { in } \\
\text { general } \\
14 \text { year in } \\
\text { brokerage }\end{array}$ & $\begin{array}{l}\text { master business } \\
\text { administration } \\
\text { (MBA) }\end{array}$ & brokerage \\
\hline M9 & $\begin{array}{l}\text { Chairman of } \\
\text { the Board of } \\
\text { Directors }\end{array}$ & 55 & 27 & PhD & Brokerage \\
\hline M10 & $\begin{array}{l}\text { financial } \\
\text { managers }\end{array}$ & 56 & 35 & $\begin{array}{l}\text { master business } \\
\text { administration } \\
\text { (MBA) }\end{array}$ & Brokerage \\
\hline M11 & $\begin{array}{l}\text { Chief executive } \\
\text { officer (CEO) }\end{array}$ & 59 & 27 & $\begin{array}{l}\text { PhD financial } \\
\text { economics }\end{array}$ & Brokerage \\
\hline
\end{tabular}


Table 2 Number and Percentage of Respondents included in Interview

\begin{tabular}{|c|c|c|c|c|}
\hline & & & No & $\%$ \\
\hline \multirow{7}{*}{$\begin{array}{l}\text { Firms' } \\
\text { Executives: }\end{array}$} & Industrial & \multirow{5}{*}{$\begin{array}{l}\text { Textile industrial co. } \\
\text { Pharmaceutical industrial } \\
\text { co. } \\
\text { Motor industrial co. }\end{array}$} & & \\
\hline & Companies: & & 1 & $9.1 \%$ \\
\hline & \multirow{5}{*}{$\begin{array}{l}\text { Service } \\
\text { Companies: }\end{array}$} & & 4 & $36.3 \%$ \\
\hline & & & 2 & $18.2 \%$ \\
\hline & & & 7 & $63.6 \%$ \\
\hline & & \multirow{2}{*}{$\begin{array}{l}\text { Hospitality and Tourism } \\
\text { co. } \\
\text { Securities Brokerage co. }\end{array}$} & $\begin{array}{l}1 \\
3 \\
\end{array}$ & $\begin{array}{l}9.1 \% \\
27.3 \% \\
\end{array}$ \\
\hline & & & 4 & $36.4 \%$ \\
\hline \multicolumn{3}{|l|}{ Total } & 11 & $100 \%$ \\
\hline
\end{tabular}

Figure (1) Interview Guide

\section{Corporate executives' self-interests motives for improving (FRs)}

\section{1) Motives related to Management Self-interests}

Opinion Question: in your opinion what are the effects of reporting losses on your self-interests?

Probing Questions, could you tell me more about

- Maintaining the present (job security)

- Enhancing professional reputation in the job market to get more prestige and better job in future

- Increasing salary and other cash bonuses

- Increasing other forms of compensations e.g. increase stock-based plan compensation

Incentives Related to Management's Self-interests and Firm's Interests

1) Opining Question: in your opinion what are the important motivations to improve the reported earnings and the financial image of your firm?

Probing Question, could you tell me more about:

- Is your firm's reputation with its outsiders or your self-interests the most important motivations for improving your company's financial image or reports? Why?

- Which incentives are more important: the monetary incentives or the job market incentives? why?

Finally, would you like to add or mention to anything else which we did not cover during our discussion about such phenomenon? 